\title{
THE URGENCY OF HUMANITIES AND SOCIAL STUDIES IN INDONESIAN EDUCATION (RESPONDING TO HUMANITIES TWILIGHT IN JAPAN)
}

\author{
Mohammad Liwa Irrubai \\ Universitas Islam Negeri Mataram, NTB, Indonesia \\ liwarubai@uinmataram.ac.id
}

\begin{abstract}
This article aims to explain the importance of humanities studies in Indonesian education, as a response to the humanities twilight pessimism in Japan. Afterward how its effect toward the continuity of humanities and social studies in Indonesian education. The study uses a qualitative approach using library research. The data analysis method applied was in meta-analysis. Based on the data and analysis, it was explained that it is reasonable if Japan wants to erase Humanities and Social Studies because of the decreasing population numbers, the lack of manpower, industrial competition and dependency to China and other countries, and the influence of Shinto teaching and Shingaku Concept inspiring Prime Minister Abe in focusing on Engineering education. This also replies to the Fukuyama's concern in the emergence of post-historic where there is no longer art and philosophy. Meanwhile, based on Constitution number 20 of 2003 on National Education system that Humanities and Social Studies is still important in achieving national education objectives as well as shaping Indonesian people thoroughly because it still having national leadership crisis, corruption emergency, drug emergency, economy that has not got better yet. It is also to create the humane people and fight for Indonesian survival. Soekarno, Mohammad Hatta, and other figures indicating that Humanities and Social Studies affect humanity, the spirit in awakening, struggle, resistance toward oppression, patriotism, and justice.
\end{abstract}

Keywords: Humanities and Social Studies, Education in Indonesia

\section{INTRODUCTION}

Indonesian objective as a country is contained in the opening of UUD 1945 in paragraph $4^{\text {th }}$ i.e.: to promote public welfare, enrich the nation's life, and participating in the world order that is based on freedom, everlasting peace, and social justice.To achieve those fourth objectives, especially in enriching the nation's lives, surely it is through education. Therefore, in Constitution Number 20 of 2003 on the National Education System, clause 3, it is said: 
Irrubai, M.L. (2020). THE URGENCY OF HUMANITIES AND SOCIAL STUDIES IN INDONESIAN EDUCATION (RESPONDING TO HUMANITIES TWILIGHT IN JAPAN). Jurnal Tatsqif, 18 (2), 183-206. https://doi.org/10.20414/jtq.v17i2.2836

"The function of national education is to develop and shape the nation's character as well as a civilization that is dignified to enrich the life of the nation, to develop and improve the potential of the student in order becoming people who believe and fear in Allah the Almighty, the student with noble character, healthy,knowledgeable, competent, creative, independent and becoming the democratic and responsible citizens."

It is very clearly mentioned above that developing studentis to become people who have faith and fear in God the Almighty, character, healthy, knowledgeable, competent, creative, independent, and becoming democratic and responsible citizens. All the objectives can be achieved using education and knowledge, one of the most contributed knowledge in establishing it is humanities and social studies.

Later on, the development of knowledge shows that: "the awareness to develop knowledge and science is a sign and the spirit of the era (Zeitgeist), because since the Renaissance, western world inherits the passion to study knowledge and Greek philosophy. The Renaissance people, such as the ancient Greek philosophers/scientist is the all-around man. For instance, Leonardo da Vinci is a great painter artist, his famous work is Mona Lisa, the Last Supper, etc. Yet, he is also a reviewer in mathematics, astronomy, human anatomy, and mechanics with his machine sketches such as a helicopter, steel car/tank for war, etc. The rapid development experiencing by natural sciences, and then it is followed by sciences on human(2015: 14-16).

The progress in science and technology is so rapid, it requires arrangement and classification so that in the 19th century, the science of sociology was pioneered by Windelband, who arranges categorization and organization of science, to ease the science used to identify which science studied. The description is in the following table:

\begin{tabular}{|l|l|l|l|}
\hline $\begin{array}{l}\text { Naturwissenschaften } \\
\text { (Natural Sciences): }\end{array}$ & $\begin{array}{l}\text { Geistewissenschaften } \\
\text { (Social Sciences): }\end{array}$ & Humanities: & Cultural Studies \\
\hline Astronomy & Anthropology & Language & Cultural Studies \\
PhysicsChe & Sociology & Art & Humanities Studies \\
mistry & Economy & ReligionPhilo & \\
Mathematic & History & sophy & \\
s & Politics & & \\
Biology & Law & & \\
Geology & Psychology & & \\
\hline
\end{tabular}

(Wiriaatmadja, 2015) 
Irrubai, M.L. (2020). THE URGENCY OF HUMANITIES AND SOCIAL STUDIES IN INDONESIAN EDUCATION (RESPONDING TO HUMANITIES TWILIGHT IN JAPAN). Jurnal Tatsqif, 18 (2), 183-206. https://doi.org/10.20414/jtq.v17i2.2836

In a further development, the above sciences have their branches and subdivisions, thanks to the previous scientific method effectiveness. For instance, in natural sciences (Naturwissenschaften), physics is divided into optical physic, electricity, sound, magnet, molecular physics, quantum physics,

In social science such as history, there is political history, social history, cultural history, territorial history as in South Asia, etc. Psychology was branched into the science of educationetc., while anthropology branched into physical anthropology and cultural anthropology etc., while philosophy branched into the philosophy of science, philosophy of history, philosophy of law, etc.

With the development of the science branch and subdivision in all categories, epistemology is also developed. Allthe humanities and social studies problems cannot be solved using the Cartesian-Newtonian science method, which is commonly known by the students as a quantitative or positivistic method. However, the problems related to human that is unique and constantly changes requires specific approaches, a qualitative type. During the post-Vietnam war, or in the decades of 1980s, qualitative method is just like naturalistic, phenomenology, criticism theory (Marxism), semiotics, ethnomethodology, and various ethical paradigm are generally conducted by humanities and social studies group (Denzin and Lincoln, 2009:12).

Using the Cartesian-Newtonian science method, and then emerges a critic from Pritjof Capra (1998) who sees the long-term impact of this method toward industrialization, causing environmental damage. Factory chimneys emitting continuous toxic fumes causes air pollution, creating a huge ozone hole in the South, the melting ice in the Northern Pole, and global warming. The direct effect we can see is the deforestation in Kalimantan and Brazil. Capra suggests an ethical Cartesian-Newtonian science method, he 
Irrubai, M.L. (2020). THE URGENCY OF HUMANITIES AND SOCIAL STUDIES IN INDONESIAN EDUCATION (RESPONDING TO HUMANITIES TWILIGHT IN JAPAN). Jurnal Tatsqif, 18 (2), 183-206. https://doi.org/10.20414/jtq.v17i2.2836

adds that its moral values from religion, especially from Chinese teachings Daoism (Lk. 600 year BC) that believes in natural balance.

Furthermore, in the book entitledFilsafat ilmu Bagi Pendidikby Anna Poedjiadi (2001: 21) it is explained the negative impact of science without morality, is that the Sciences earlier has kept on developing rapidly and producing many technological products that are useful to society, unfortunately,many negative impacts are emerging from the development of the science. Surely, you still remember how powerful the explosion of the atomic bomb dropped on Hiroshima and Nagasaki city in 1945 in Japan. The bombings causingmost of the city destroyed and many citizens were dead. Some of them suffered injuries and disabilities for the rest of their life. This is an example of human tragedy caused by the usage of scientific progress on nuclear energy with its technological product. The story brought to our senses of the necessity in discussing science development on its morality, norms ethics, and spiritual aspect.

From the above description, it can be noted that science development is not merely being formulated or determined by the science itself but it needs to be correlated with the basic culture of the society or nation. This is because fundamentally, the value of science development needs to be reviewed on how far the knowledge can contribute to the welfare of the society without sacrificing their cultural values. Therefore, an understanding of the philosophy of science is very much needed.

\section{THEORETICAL FRAMEWORK}

On this theoretical framework, the writer will use some of the concepts and theories that will be used to discuss the above problems, as follows:

\section{Humanities and Social Studies in Education}

The term of Social Science, or commonly known as IPS (Social Science), is a subject in elementary school and Junior High level or the name of the 
Irrubai, M.L. (2020). THE URGENCY OF HUMANITIES AND SOCIAL STUDIES IN INDONESIAN EDUCATION (RESPONDING TO HUMANITIES TWILIGHT IN JAPAN). Jurnal Tatsqif, 18 (2), 183-206. https://doi.org/10.20414/jtq.v17i2.2836

department in universities that is identical with the term "social studies". In another country's school curriculum, especially in western countries such as Australia and the United States, the term "IPS" is commonly known as social studies in another country. It is the term resulted from the Indonesian experts or specialists concession in the National Seminar about Civic Educationin 1972 in Tawangmangu, Solo, that IPS as a school subject firstly introduced in the 1975 Curriculum.(Sapriya, 2009, 19).

In western countries, the term Social Studiesfirst time used by Edgar Bruce Wesley which is also called a historical pillar. He expresses that "Social Studies are the Social Sciences Simplifying Pedagogical Purpose”. It means that social Studiesaims solely for education. This definition isstandardized in The United States of Education's Standard Terminology for Curriculum and Instruction as follows: "the Social Studies comprised of those aspects of history, economics, political science, sociology, anthropology, psychology, geography, and philosophy which in practice are selected for purposes in school and colleges".(Dadang supardan, 2015: 9).

While in National Council for the Social Studiesor NCSS it is stated: "Social Studies is the basic subject of the K-12 curriculum that (1) derives its goals from the nature citizenship and the democratic society that is closely linked to other nations and people of the world; (2) draw its content primarily from history, the social sciences, and in some respect from humanities and science; and (3) is taught in ways that reflect an awareness of the personal, social, and cultural experiences and developmental level of learners" ".(Dadang supardan, 2015: 9).

In Indonesia, experts views on Social Studies in IKIP Bandung (Currently UPI). Social Studies expert's opinion such as Achmad Sanusi, says that discussing the interdisciplinary-analytical on social issues chosen, empirical, and contemporary. ".(Dadang supardan, 2015: 9).The limitation implies that social studies are a study with an interdisciplinary approach toward meaningful social issues. The characteristics that can be seen in this study is 
Irrubai, M.L. (2020). THE URGENCY OF HUMANITIES AND SOCIAL STUDIES IN INDONESIAN EDUCATION (RESPONDING TO HUMANITIES TWILIGHT IN JAPAN). Jurnal Tatsqif, 18 (2), 183-206. https://doi.org/10.20414/jtq.v17i2.2836

problem-oriented scientific organized and interdisciplinary approach.It seems the concept is correct for a university. In other writing, it is stressed that social studies should have an educational function and intellectual practice, which is introduced with BASK conception.

Meanwhile, Muhammad Nu'man Somantri on Social Science, we can understand his thought, that the features of Social Studies were seen by the way of organizing lesson material which emphasizes scientific and psychology. And also we could understand that social studies must be precise in maintaining its scientific element. Meantime, as a learning program, it must be organized in such a way so that it is enough to exhibit the student's development. Another Natural Science figure is A. Kosasih Djahiri who defines it as follows: IPS (Social Studies or Social Science) is knowledge that mixes some selected concept from the branches in the Social Science and other science, afterward, it is arranged based on the educational and didactics principle to be used as a learning program in the school level. From the explanation, Social Studies is a science, it is the knowledge presented in the form of fusion of selected concepts, which its ingredients are organized in such a way so that it fulfills the requirement of a learning program.

However, the emphasis is on the learning principles applied completely and comprehensively in all educational and class level. Social studies learning, should be a strong and powerful lesson with a basis on the meaningful, integrative, value-based, challenging, and activating student's learning. (NCSS. (1979: 3).

It is a very important, complex, and hard task to prepare studentsto become democratic citizens. Social Studies which is mixed from various social science disciplines includes various expansive and potential content. The content involves the students in the comprehensive process of dealing with some dilemmas and encouraging the student to reflect on the social issues, critically-thinking, and making individual or group decisions based on information from various perspectives. A strong and firm social studies 
Irrubai, M.L. (2020). THE URGENCY OF HUMANITIES AND SOCIAL STUDIES IN INDONESIAN EDUCATION (RESPONDING TO HUMANITIES TWILIGHT IN JAPAN). Jurnal Tatsqif, 18 (2), 183-206. https://doi.org/10.20414/jtq.v17i2.2836

curriculum will provide complete and comprehensive learning activities and strategies. Such learning must involve students with significant brilliant ideas, and encourages them to relate what they are learning and what knowledge previously they have as well as current issues, thinking creatively and critically on what they are learning, and applying it to the authentic situation. (C. Z. Sunal, and M. E. Haas, 1993: 53).

The social science objective in Junior High School is to foster the student becoming a citizen that is wanted by the country and society. Such a goal is an educational formal and moral responsibility of a scientific discipline at the school level. In the social studies objective formulation according to NCSS, it is explained that the primary goal is to develop the youth, in this case, the students or pupil, developing an ability to make decision rationally for the sake of public interest as a diverse democratic citizen in the interdependence of the world. In other words, the primary objective of social studies is to develop the student's potential to sensible toward social issues occurred in society, have a positive mental attitude in the improvement of occurred imbalance, and skillful in solving every problem occurred daily either an individual or societal problems. The objective can be achieved when Social studies learning programs is well-organized.

Social studies objective according to NCSS becomes a reference of the experts. Jarolimek (2002) writes on social studies purpose:"the major mission of social studies education is to help children learn about the social world in which they live and how it got that way; to learn to cope with social realities, and to develop the knowledge, attitudes, and skills needed to help shape an enlightened humanity. (J. Jarolimek, 2002: 4).

It is clear, Jarolimek expresses that fundamentally social studies have a mission for the pupil to study and understand the social surrounding environment by developing knowledge, behavior, and competence that will support in a people's life. As a subject, social studies aims to develop knowledge, attitude, and skill in the concept and learning experience selected or organized for the study of social sciences.

Zevin (2007) writes that fundamentally social science purpose covers three aspects, i.e.:

a. The didactic goal, i.e.: transmitting knowledge about the past. 
Irrubai, M.L. (2020). THE URGENCY OF HUMANITIES AND SOCIAL STUDIES IN INDONESIAN EDUCATION (RESPONDING TO HUMANITIES TWILIGHT IN JAPAN). Jurnal Tatsqif, 18 (2), 183-206. https://doi.org/10.20414/jtq.v17i2.2836

b. The reflective goal, i.e.: concluding, analyzing, and applying information and data.

c. The affective goal, i.e.: covering moral, feeling, emotion, and value. Chapin and Messick (1992), conveys the goals of learning as follows:

a. Providing knowledge of human experience in the society of the past, present, and future.

b. Developing skill to find and processing information

c. Developing democratic values attitude within society

d. Giving student chances to have participated in social life

e. Dedicated to the student to understand concrete and realistic things in social life.

Awan Mutakin says the goal of social studies is to assist an individual to develop the knowledge aspect, skills, and values as well as understanding the need fora human relationship, civic responsibility, economic competence,and thinking ability.

The objective of social science can be well-achieved when the lesson material is organized in diverse starting from the approach of monostructure discipline, infrastructure, and trans-structure social science discipline, with Pancasila as the central values according to the institutional objective of an educational institution. Generally, the purpose of social science is to form a student or pupil becoming a responsible citizen, who are understand its rights, responsibility, and obligations.

Dadan Supardan (2013) explains; the origins of our assumptions and commitments in the history of education are lopsided if it is not accompanied by critical thinking. Because many cases occurred among educational historians is susceptible to make romanticizing public education as a "great equalizer" in a democratic society. This is proven if we learned the course of education history. They are easy to neglect the undemocratic experience especially within political domination: economic exploitation, cultural penetration, labor, or gender. Moreover, in reality, the problem is so broad and complex, either in the era of VOC, Dutch Colonial, Ethical Politic, Japan Occupation Era, Independence Era, Old Order Era, New Order Era, or Reformation Era. For an individual with radical critical education, it must 
Irrubai, M.L. (2020). THE URGENCY OF HUMANITIES AND SOCIAL STUDIES IN INDONESIAN EDUCATION (RESPONDING TO HUMANITIES TWILIGHT IN JAPAN). Jurnal Tatsqif, 18 (2), 183-206. https://doi.org/10.20414/jtq.v17i2.2836

breach the school's boundaries in the public domain, and political. The task means to make pedagogical become more political, and make political more pedagogical.

\section{METHOD}

The study uses a qualitative approach with library research method by studying concept, the famous figure's opinion related to Humanities and Social Studies by discussing relevant scientific treasure. The data analysis method used is a meta-analysis, which is problem analysis and variable to determine the relation of inter variable.

\section{DISCUSSION}

\section{Humanities and Social Studies in Japan}

Japan's population is getting decreasing. This condition has occurred for four years.

Japan's population number has gone back to the same amount as in 2000 . According to the data released by Japan's Government, the population is decreasing 0.17 percent or 215.000 people of 127.083 .000 citizens per 1 October in 2014. The number has included foreign people who have long-lived in Japan. Meanwhile, the number of Japan's citizens who were 65 years old or more is increasing from 1.1 million to 33 million. The number of citizens who were elderly is now exceeding the number of the 14 years old or younger citizens with the comparison of $2: 1$.

The other problem in Japan, there is very little immigration. Japan's government has warned that it is estimated its population will decrease to 86.7 million people in 2060, with the proportion of citizens of 65 years old or more is estimated atnearly 40 percent of the total population in Japan.

While in Education, based on the Ministry of Education, Culture, Sport, Science, and Technology's policy, there is the instruction to erase humanities and social studies. Two universities with the highest ranks in Japan reject to erase it. However, many universities in the country obey the rule. Back then, in June 2015, around half of 60 state universities in Japan with its faculty of 
Irrubai, M.L. (2020). THE URGENCY OF HUMANITIES AND SOCIAL STUDIES IN INDONESIAN EDUCATION (RESPONDING TO HUMANITIES TWILIGHT IN JAPAN). Jurnal Tatsqif, 18 (2), 183-206. https://doi.org/10.20414/jtq.v17i2.2836

humanities and social studies were planning to erase the departments and faculties in several academic years afterward.

This fact was found through a survey conducted by Yomiuri Shimbun. Based on the survey, there is 26 president of the state universities decides to eliminate the related departments. Hence, in the future in some universities, there would be no longer students of Economy, law, politics, sociology, or literature. It is estimated that the policy will create dramatic changes impactedon Japan's future to come.

The dramatic changes meant here is a bad effect because if Japan focuses to increase its engineers' number, they will go back to the development era of a developing country. In the current position,advanced Japan also needs humanities and social studies experts to manage all of their development.

Japan's productivity was regarded as progressing very slow since the beginning of the 1990s period. And they require financial experts to help in mapping their savings from the past, waning industrial sector, and direction to productivity. They will also need law practitioners to handleintellectual rights property and help the businesses navigating the international law system. There will be needed consultants evaluating unbeneficial operational activity, stagnant companies, and assist companies to regain their benefit(The Japan News, 2020).

In Japan, the compulsory education program starts from the age of 6 to 15 years. The new school year starts in April so that a child who has entered 6 years old on 1 April must have to enter an Elementary School (SD). After finishing compulsory education for 6 years, they will start entering Junior High School (SMP), added another 3 years.

After finishing the compulsory education program, the students have some options. There are numerous institutions offered to study for those who are 15 until 18 years, including High School which offers general education, or agriculture, industry, and commercial. There is also the opportunity to gain a degree in High School in the night school or via 
Irrubai, M.L. (2020). THE URGENCY OF HUMANITIES AND SOCIAL STUDIES IN INDONESIAN EDUCATION (RESPONDING TO HUMANITIES TWILIGHT IN JAPAN). Jurnal Tatsqif, 18 (2), 183-206. https://doi.org/10.20414/jtq.v17i2.2836

correspondence while working. Meanwhile, there is also a school of technology for five years that dominating general education with special engineering training. In Japan, as much as $98.1 \%$ of graduates of Junior High continue their study in one of the options mentioned earlier.

On the level of higher education, some universities offer 4 years program, a diploma school for 2 years, and senmon gakkou (vocational school) with 2 years or more program. After graduating from university, the students may continue their education for another 2 years for a specialist degree in a master's program or 3 years or more for a doctoral degree. Most companies in Japan require a minimum university degree for job seekers.

In 2019, as much as 50.8\% of High School graduates were successful in the university admission test. Even so, as much as $97 \%$ of High School graduates in Japan were still can get their job. For the High School graduates who have taught of their future, senmon gakkou is a popular choice. Many institutions also offer various education, such as nursery, cooking, agriculture, civil engineering, and construction, anime, linguistics, video game, film, and theater, as well as sports.(Sumber: Nippon, 1 April 2020)

In the meantime, the influence of Shintoism and the State toward Japanese people in this modern era, effect the need to cooperate and collaborate, it can be seen in entire Japan's civilization even until today. Thus, in modern Japan's companies, there is no action taken before a consensus is achieved (even if there is, it is only superficial) by all parties to make their decisions.

The influence of Shintoism andthe Economy can be explained as follows:Japan is a smart country in combining modern with traditional harmony. This can be seen in the attitude of this country in many ways, on the spirit of Confucianism and Shintoism which has become the feature in social life and business ethic.

While Shingaku concept is a movement delivered by a person named Ishida Bagian (1685-1744). He gives the first public lecture in 1927. He 
Irrubai, M.L. (2020). THE URGENCY OF HUMANITIES AND SOCIAL STUDIES IN INDONESIAN EDUCATION (RESPONDING TO HUMANITIES TWILIGHT IN JAPAN). Jurnal Tatsqif, 18 (2), 183-206. https://doi.org/10.20414/jtq.v17i2.2836

judges that all of the teachings as "the mind-clearing method" (kokoro wo migaku togikusa, as recorded in his book Tohi mondo), to see a person's mind (kokoro) as a central actor. He also promotes "ways to commerce" and the daily practice of noble ideals such as honesty and frugality. Thus, indirectly it teaches the Japanese to be honest in a trade.

In the Industrial field, as it is known, Japan's economic growth once suffered a contraction in the period April-June 2015, and then because of the Chinese economic recession. Japan's government itself has cut down its country's economic assessment by considering the low export demand. These days it has affected the collapse of industrial activities in the country until the last August, it still survives on the negative territory. As information, until last September, the sluggish export activities have been reported, so does the import. Nevertheless, it seems the challenge is not decreasing the manufacturing performance in the country.

It is because it quite the opposite with the Chinese manufacturing performance that has a touching contraction phase for the last one year. the manufacturing activity in Japan in October on the contrary has run for 6 months straight, succeeded in its expansion phase because of numerous domestic demand, and the new export in this country increases whereas Japan's manufacture PMI in this month touching the level of 52,4. As information, Japan's manufacturing activity this October is the strongest within the last one year (Vibiznews, downloaded on 3 April 2020).

On the other hand, Japan's manufacture is rising so fast, even though it is also influenced by other country's market such as the Chinese, their closest neighbor, as expressed by Immanuel Kantthat the international commerce will create a degree of inter-depending that will make war that will be opposing on our selfish interest (Loren, 2002).

The theory of progress argued by Auguste Comte; political leaders to determine the policy ensuring that people will live together in harmony, whereas the humane industrialist will provide tools for a human to fulfill their material need adequately. Fukuyama's concern on the emergence of post-historic where there are no longer art and philosophy. 
Irrubai, M.L. (2020). THE URGENCY OF HUMANITIES AND SOCIAL STUDIES IN INDONESIAN EDUCATION (RESPONDING TO HUMANITIES TWILIGHT IN JAPAN). Jurnal Tatsqif, 18 (2), 183-206. https://doi.org/10.20414/jtq.v17i2.2836

Based on the data and the above analysis, it can be concluded that it is reasonable for Japan wants to erase Humanities and Social Studies because of the decreasing population, the lack of manpower, competition, and industrial dependency with a neighboring country such as China and other countries, and the influence of Shinto and Shingaku concept inspiring Prime Minister Abe to focus on engineering education. This also answers Fukuyama's concern in the emergence of post-historic where there are no longer art and philosophy.

What would it become if a country without Humanities and Social Studies? The answer is the loss of humanity. What is shocking is that there is a country in this world-leading to the direction. As issued by Kompas Daily, Japan's Government under Shinzo Abe Prime Minister instructed to close all humanities and social studies in the 60 states universities of the country. As much as 26 universities have confirmed will erase or re-considering the policy of the Prime Minister originated from Liberal Democratic Party (LDP). The reason for it is because humanities and social studies do not have its practical benefit so it should be closed and replaced with other educational science that is more obvious in its practical benefit.

It seems what Shinzo Abe's do is in line with the Theory of Progress, Doyle Paul Johnson in the book entitled "Teori Sosiologi Klasik dan Modern" (1986: 94-95), Auguste Comte states:

The evolution process must be continue assisted by human effort. Even though Comte believes that the development of Positivism will be causing continuous progress, it is certain. His theory implies that history moves to the end, that every previous historical event is important, especially because of its contribution toward the end. The final stage of society is where the intellectual and moral guidance given by the Sociological cleric will allow the political leaders to determine policy ensuring that people will live on together along in harmony, whereas the humane industrialist will provide tools for fulfilling its material need adequately.

This is strengthened by what it is concerned by Fukuyama in the book entitled The Future of The World, Masa Depan Peradaban dalam Cengkraman Demokrasi Liberal versus Pluralisme (2005: 32-33), states that: 
Irrubai, M.L. (2020). THE URGENCY OF HUMANITIES AND SOCIAL STUDIES IN INDONESIAN EDUCATION (RESPONDING TO HUMANITIES TWILIGHT IN JAPAN). Jurnal Tatsqif, 18 (2), 183-206. https://doi.org/10.20414/jtq.v17i2.2836

The first alternative to liberalism in Asia that was badly defeated was Japanese imperial fascism. Japanese fascism (like German Fascism) was defeated by the strength of American weaponry in the Pacific War, and liberal democracy was instilled by the United States. Western political capitalism and liberalism when applied to Japan were adapted and transformed in such a way that it was almost unrecognizable. The main elements of economic and political liberalism have been so ingrained in Japanese traditions and institutions that this uniquely ensuring the everlasting long-term element. Importantly, Japan's contribution to the world's history by following the Americans in creating a consumptive culture that is truly universal and has become the symbol and pillar of the universal homogeneous country. VS. Naipaul, who visited Ayatollah Khomeini's post-revolution Iran, noted advertisements everywhere offering Sony, Hitachi, and JVD products. The attractiveness of these products remains irresistible and goes against the pretense of the regime to restore the State based on shari'a law. The desire to enjoy a consumptive culture, created primarily by Japan, has played an important role in promoting the spread of economic liberalism throughout Asia, and then political liberalism as well.

The economic success of several New Industrial Countries (NIC) in Asia following Japan has become a common story. What is important according to Hegel is that political liberalism even though not run as fast as expected by many, certainly will occur. Here we witness again the triumph ideas of homogeny universal country.

However, behind the success of Japan's economy, the end of history is a very pathetic period. The struggle to gain acknowledgment, the willingness to sacrifice life for an abstract goal, the world ideology struggle demands courage, passion, imagination, and idealism will be replaced by economic calculation, solving endless technical problems, environmental issues, and satisfying highly tasted consumer demand.

In this post-historic period that there is no art or philosophy, only the continuous maintenance of a museum of human history. Fukuyama (2005) states:

I can feel inside of me and see in the people surrounding me, a strong nostalgia for an era when history was still around. This kind of nostalgia is actually will keep on triggering competition and conflict even in the post-historic world for some future to come. Even though I could see it inevitable, I have very ambiguous feelings about the civilization that has been created in Europe since 1945, with its branches in the North Atlantic and Asia. It is might be the boredom prospect for centuries will create the history come back again.

\section{Terry Eagleton in his book The Slow Death of University assumes that:}

"The death" of Humanities and Social Studies is the same as "the death" of the university itself because the first time philosophical foundationof the university comes from humanities and social studies. Eagleton's view can become a warning for us that the death of humanities and social studies is not only the sign of the death of the universities in the world itself. 
Irrubai, M.L. (2020). THE URGENCY OF HUMANITIES AND SOCIAL STUDIES IN INDONESIAN EDUCATION (RESPONDING TO HUMANITIES TWILIGHT IN JAPAN). Jurnal Tatsqif, 18 (2), 183-206. https://doi.org/10.20414/jtq.v17i2.2836

\section{Humanities and Social Studies Education in Indonesia}

Central Bureau of Statistics (BPS) reports that based on the Survey in 2014 and 2015, the Indonesian population reached 254.9 million. The data shows, out of the total amount, male populations are 128.1 million while female populations are 126.8 million. On the other hand, Indonesia is an agricultural and maritime country as well as a developing country, this means that Indonesia has not been included as an industrial country globally and has a different need from Japan.

Meanwhile, Education in Indonesia can be explained as follows: Higher Education has two main roles: (1) providing education service for the young productive age citizen; and (2) developing science and technology through research which producing invention and innovation. These two central roles are closely related to economic development. The success of economic development is determined by, i.e. high educated people, knowledgeable, possess technical skills and proficiency, and technology savvy.

According to Forlap's data, Kemenristekdikti(2020)explains:

The number of departments in higher education are 23.747. This is categorized into two fields of studies: (i) science-engineeringincluding, among other, Mathematics and Natural Sciences (MIPA), engineering, medicine, health, and agriculture; and (ii) humanities-social studies covering, among others, economy, management, politic, law, sociology, anthropology, history, philosophy, and religion.

The number of departments in the science-engineering field is as much as $10,135(43 \%)$ less than humanities-social studies, as much as 13,611 (57\%). The department composition according to the field is unbalanced. If it is seen from the student's number according to the study of each department, the number is more evident. Of the total students of $5,228,561$ in all departments, they who entering science-engineering are only $1,593,882(30.5 \%)$, while those who enter in humanities-social studies are as much as 3,634,679 (69.5\%).(Source: Kompas Dailyedition 7 April 2020, on page 7 with the title "Bidang Ilmu di Perguruan Tinggi)".

The graduates produced by higher education institutions are inevitably dominated by those who are engaged in the social and humanities sciences. Inaccuracy in designing department composition and total student body according to the science field has to create bachelors inflation of humanitiessocial studies. In the context of the job market, there is an imbalance in the supply and demand that impacted the difficulty to find a job. Bachelors of 
Irrubai, M.L. (2020). THE URGENCY OF HUMANITIES AND SOCIAL STUDIES IN INDONESIAN EDUCATION (RESPONDING TO HUMANITIES TWILIGHT IN JAPAN). Jurnal Tatsqif, 18 (2), 183-206. https://doi.org/10.20414/jtq.v17i2.2836

humanities-social studies are over-supplied, while bachelor of scienceengineering is increasingly in demand that cannot be fulfilled entirely by higher education.

The deficit of engineering bachelor, England's prominent magazine, The Economist (2015), refer to Indonesian Engineers Union (PII), reviews clearly that within the next 10 years to come (2015-2025) Indonesia will shortage of engineer with an average of 15,000 per year. In this period between 2015-2020 and 2020-2025, the need forthe engineer in each year is around 90,500 people per year and 129,500 people per year. Unfortunately, higher education is only capable of generating around 75,000 and 120,000 people. The data of UNESCO Institute for Statistics (UIS, 2013-2015) shows the ratio of engineering bachelor per 1 million population in this country is really low compared to other countries, in consecutiveIndonesia $(2,671)$, Malaysia $(3,334)$, India $(3,380)$, Thailand $(4,421)$, and China(5,730).There are far fewer scientists who pursue the profession as researchers, it is reflected in the researcher's ratio per 1 million population, consecutively Indonesia $(1,070)$, Malaysia $(2,590)$, Japan $(5,570)$, Singapore $(7,115)$, and South Korea $(8,105)$.(Source: Kompas Daily edition 7 April 2020, on page 7 with the title "Bidang Ilmu di Perguruan Tinggi)".

The shortcoming of engineering bachelor impacts on the availability of especially skilled manpower, especially in the infrastructure and manufacture industry. When the ASEAN Economic Community applied in January 2020, the shortage of engineering bachelor has become a serious issue. Now, the mobility of manpower inter-country has opened so that Indonesia must be ready to receive the presence of many engineers from ASEAN countries to work, especially in the infrastructure sector.

Therefore, there is no other option for the Indonesian government and higher education, except to make policy by changing department proportion and design students amount between the study of science-engineering and humanities-social.

The Rector of the Sepuluh Nopember Institute of Technology Surabaya Tri Yogi Yuwono says:

The government needs to take sides in developing engineering study programs for the needs of Indonesian skilled workers. The country only produces 164 engineering graduates per 1 million population. The neighboring countries, such as Malaysia, produce 300 engineering graduates per one million population. Meanwhile, South Korea produces 800 engineering graduates per 1 million population. Ideally, Indonesia can produce 600 engineering graduates per 1 million population. "If the efforts to improve Engineering study programs in tertiary institutions are mediocre, without any breakthroughs, we will lack technical experts. For domestic needs are lacking, how can we look at foreign markets in the era of free markets that are in sight,Said Try. (Kompas Dailyedition 7 April 2019, on page 7 with the title "Bidang Ilmu di Perguruan Tinggi). 
Registration for National Selection for State Universities is officially closed on Monday (14/3/2019) at22.00. The committee announces that out of 1.3 million Indonesian students who are categorized worthy in registration, it is selected 645,134 people have been finalized. The data shows that 96,539 students are accessing the registration website of National Selection Entering State Higher Education (SNMPTN), but not continue their registration. Moreover, there is 8,625 student who has registered, but not finalizes so that automatically their names are not included in the selected students.

"Majority of the student did not finalize their registration comes from Vocational School," Said Rochmat Wahab, the chairman of SNMPTN committee, when he is contacted from Jakarta, Monday night, after the closing registration. He said the average of registrators are High School students and Madrasah Aliyah.

On a separate occasion, the Counseling Guidance teacher of SMKN 15 South Jakarta, Citradewi, says that out of 180 students in class XII, only 20 students participated in SNMPTN. Generally, they register in state polytechnic to enrich their working skill. The rest of them choose to work first. "Some of the companies also have a college scholarship to the selected employee. So, must of the student consider that the study can be continued while they are working and save money to provide their life cost," (Kompas Siang | 15 March2019)

How about in Indonesia, it seems that the people wants practical. The reasoning used by Abe is often seen in our surroundings. It has been since then, humanities and social studies are regarded as second class departments, even in high school, the students who enter social studies and languages are considered as "leftover" students. Then where does this kind of thinking come from? 
Irrubai, M.L. (2020). THE URGENCY OF HUMANITIES AND SOCIAL STUDIES IN INDONESIAN EDUCATION (RESPONDING TO HUMANITIES TWILIGHT IN JAPAN). Jurnal Tatsqif, 18 (2), 183-206. https://doi.org/10.20414/jtq.v17i2.2836

If we borrow the theory Labeling theory's perspective introduced by a Sociologist in Chicago' School in the 1960-1970s, which is George Herbert Mead in his book entitled, "Labeling theory: Social constructionism, Social stigma, Deinstitutionalization," it is explained that behavior and identity of the individual are determined or influenced by a social structure where they belong to. Individual divergence behavior does not necessarily inherent within the individual but it is identified or labeled socially by society.

Borrowing the Labeling approach above, an assumption that natural science and engineering represents the smart student and humanities and social studies represent the not smart students, are from labeling either from the educator in the past or the student's parent which was taken for granted by the students in the era. Later on, it sticks in their mind until they grow up and becoming parents, then inherits the stigma to their beloving children. It means this way of thinking is reproduced continuously for decades. "It means, this way of thinking is reproduced continuously for decades".

If we traced back to human civilization, the initial point of "the death" in humanities and social studies is the industrial revolution and capitalism that are "popular" in England in the 18 ${ }^{\text {th }}$ century. Since then the way of thinking that every social science must have a practical use for industrial need coming from.

The entry of capitalism into our world of education, which began in the New Order era, also nurtures such a mindset. The New Order government in the era is at its peak to build and design in such a way the educational system in this country correspond to the need of industrial and development which is indeed more requires bachelor in natural science and engineering than humanities and social studies. The humanities and social studies in the New Order era are intentionally dwarfed to decrease the critical thinking of the people in the era.

Peter McLaren, a Pedagogical professor from the United States, also warnsin the danger of capitalism on education. According to him, the 
Irrubai, M.L. (2020). THE URGENCY OF HUMANITIES AND SOCIAL STUDIES IN INDONESIAN EDUCATION (RESPONDING TO HUMANITIES TWILIGHT IN JAPAN). Jurnal Tatsqif, 18 (2), 183-206. https://doi.org/10.20414/jtq.v17i2.2836

mixtureof positivist culture with capitalism will extinguish the subjectivecritical aspect of education. As the result, the knowledge given to the student is just another science used for industrial purposes, it is not a science to develop an ability to see life phenomena critically.

According to McLaren, as in Critical Education School, three impacts are emerging from the capitalism of education, i.e.:

(1) The presence of school practice which supports economic control by the elite class;

(2) the developed knowledge is merely to gain material profit instead to create a better global life; (3) creating a foundation for science that emphasizes corporate values at the expense of values of social justice and human dignity.

The current Indonesian government has also inherited this practical view. Some time ago, the Ministry of Research and Higher Education lead by Mohammad Nasir was planning to change research which previously from upstream to downstream into conversely. It means the research conducted was adjusted to the requirement of the market or industry. All these years, according to him, many research outcome conducted does not conform to industrial demand. Ironic, indeed, considering that Nasir is a scientist from humanities and social studies. As if he forgot that humanities and social studies brought emancipatory spirit which the benefit is not just for industrial demand and the capitalist order but also for sake of humanity along with the civilization.

In the context of the job market, there is an imbalance between supply and demand that is impacted by the difficulty to find a job. Humanities and social studies bachelor is oversupply, while engineering-science bachelor is increasingly in demand which entirely cannot be supplied by the higher education. The country only produces 164 bachelors per 1 million population.

Prominent England's magazine, The Economist (2015), refers to the data from Indonesian Engineers Union (PII), reviewing firmly within the next 10 years (2015-2025) Indonesia will shortage in engineers around 15,000 per 
Irrubai, M.L. (2020). THE URGENCY OF HUMANITIES AND SOCIAL STUDIES IN INDONESIAN EDUCATION (RESPONDING TO HUMANITIES TWILIGHT IN JAPAN). Jurnal Tatsqif, 18 (2), 183-206. https://doi.org/10.20414/jtq.v17i2.2836

year. In the period between 2015-2020 and 2020-2025, the need for engineers each year is 90,500 people per year and 129,500 people per year.

Social Humanities, creativity, precision, and concern taught in humanities and social studies will see the problem more clearly. The changes generated by humanities and social science will last longer because of their intangible nature. John Maynard Keynes may not help directly many people who lost their job during the Great Depression struck the United States and most of the world in the 1930s, but his ideas help the world to get out of the situation. Jamaluddin al-Afghani may not once free a nation, but he moves the spirit of the occupied nation to fight for their independence through his Pan Islamism. Karl Marx may not once ever liberate oppressed labor, but his notions will move the laborers in the world to demand their rights. Max Weber may not once give public service to many people, but his ideas on the current bureaucracy make the public service can run in an orderly fashion. Anthony Giddens may not once become a politician that moves the transformation in his country, but his ideas on the Third Way ideology inspiring the former Prime Minister from Labor Party, Tony Blair to make changes in the land of Queen Elizabeth II.

Afterward, what will occur to civilization if there are no longer exist humanities and social studies? Soekarno without humanities and social studies will never be the great leader of our nation. He might only become an engineer of Dutch Colonial. Without humanities and social science instead of becoming a humanist priest and developing settlement of the Kali Code, Romo Mangun may only be an architect who waiting for a construction project. Tan Malaka without humanities and social studies may never be a revolutionary figure. He might have only become a teacher in Kweekschool of the Dutch Colonial. Mahatma Gandhi without humanities and social studies will never be a compassionate human who succeeds in liberating India without a battle. He might be only become a lawyer who enjoys income from the English. Nelson Mandela without humanities and social studies will never 
Irrubai, M.L. (2020). THE URGENCY OF HUMANITIES AND SOCIAL STUDIES IN INDONESIAN EDUCATION (RESPONDING TO HUMANITIES TWILIGHT IN JAPAN). Jurnal Tatsqif, 18 (2), 183-206. https://doi.org/10.20414/jtq.v17i2.2836

be big-spirited forgiving who can forgive the warden whoever peed on him. He might be after getting out of prison will sentence to death by the officer.

In Indonesia, with the existence of article 3, Constitution Number 20 of 2003 on National Education system, says:

"The function of national education is to develop and shape the nation's character as well as the civilization that is dignified to enrich the life of the nation, to develop and improve the potential of the student in order becoming people who believe and fear in Allah the Almighty, the student with noble character, healthy, knowledgeable, competent, creative, independent and becoming the democratic and responsible citizens".

Based on the data and the Constitution Number 20 of 2003 on the National Education system above, the writer argues that in Indonesia, humanities and social studies are still important in creating Indonesian national education objectives as well as to form Indonesian peoplethoroughly, because Indonesia still suffers on the national leadership crisis, corruption emergency, drugs emergency, economy that has not yet improved to its full potential. So does to create a humanist people and struggle for the survival in Indonesia, Soekarno, Mohammad Hatta, Nelson Mandela,and other famous figures, indicated that humanities and social studies effects on humanity, the spirit in awakening, struggle, resistance toward oppression, patriotism, and justice, which all of it starts with humanities and social studies to strengthen education position, the awareness of nationality and unity.

It is strengthened by the role of humanities-social studies: First, the humanities-social scientist can make scientific studies through empirical research to describe the problems that emerge in the society and gather strategic issues that are needed to be accommodated in the development planning. The scientific study can be in the form of policy research which making policy recommendations to handle crucial problems in development.

Second,the humanities-social studies scientist also analyze the negative impact of development in society. Social scientists such as sociologists and anthropologists can give policy input and suggestions in order the negative 
Irrubai, M.L. (2020). THE URGENCY OF HUMANITIES AND SOCIAL STUDIES IN INDONESIAN EDUCATION (RESPONDING TO HUMANITIES TWILIGHT IN JAPAN). Jurnal Tatsqif, 18 (2), 183-206. https://doi.org/10.20414/jtq.v17i2.2836

impact of the development projects can be eliminated, at least minimized. The role of humanities-social studies is very central to show the road map in order the development can give benefit to society.

It is no doubt that both knowledge humanities-social studies and scienceengineering are contributing to the development. Both sciencesaremuch needed according to each portion, which cannot be replaced by one another.This is the same stated by Anis Baswedan, Mendikbud (Kompas, 28 October 2014, downloaded on 29 March2020): the awareness of the necessity of a unifying instrument is the foundation of a nation. We must aware the diversity is a fact and not a problem. If unity is regarded as a problem, so it must be united and equalized. Let us not see diversity as a problem. Don't! If the opinion emerges, we should change it. Therefore, accept diversity, educate diversity, and get used to diversity. Such as in men and women, is that a problem? No! It is a fact. Thus, educate it to respect men and women. We don't take it as a problem. It means that education is national awareness and diversity will still live with the presence of humanities and social science, which is education, tolerance, and law.

\section{CONCLUSION}

From the above discussion, it can be derived conclusion, based on the data and analysis above, the writer concludes that it is reasonable if Japan wants to erase Humanities and Social Science because of their decreasing population, decreasing manpower, industrial competition, and dependency with China and neighboring countries, and the influence on Shinto and Shingaku Concept inspiring Prime Minister Abe to focus on engineering education. This also responses to Fukuyama's concern on the emergence of post-historic that there are no longer art and philosophy.

Based on the data and the Constitution Number 20 of 2003 on National Education system above, according to the writer that Humanities and Social Studies still have an important role in creating Indonesian national education 
Irrubai, M.L. (2020). THE URGENCY OF HUMANITIES AND SOCIAL STUDIES IN INDONESIAN EDUCATION (RESPONDING TO HUMANITIES TWILIGHT IN JAPAN). Jurnal Tatsqif, 18 (2), 183-206. https://doi.org/10.20414/jtq.v17i2.2836

objective as well as forming the thoroughly Indonesian people. It is because Indonesia is still in the national leadership crisis, corruption emergency, drugs emergency,economy that has not yet improved to its full potential. It is also to born a humane people and struggle for the survival of Indonesia, Soekarno, Mohammad Hatta, Nelson Mandela,and other famous figures. This indicated that Humanities and Social Studies influence the humanity, spirit of awakening, struggle, and resistance on oppression, patriotism, and justice, which all of it starts with the importance of humanities and social studies to strengthen education in Indonesia.

\section{BIBLIOGRAPHY}

Banks, J. A. Teaching Strategies for The Social Studies. New York: Longman 1990.

Dadang S.(2008), MenyingkapPerkembangan Pendidikan Sejak Masa Kolonial Hingga Sekarang: Perspektif Pendidikan Kritisoleh, Generasi Kampus, Vol. 1, No. 2.

Faisal, Sanapiah, 1990, Penelitian Kualitatif, Dasar dan Aplikasi, Malang: YA3. Fukuyama, F. dan Huntingtong, S.P., 2005, The Future of The World, Masa Depan Peradaban dalam Cengkraman Demokrasi Liberal versus Pluralisme, Yogyakarta: IRCiSoD.

Jarolimek, J..Social Studies in Elementary Education, Seventh Edition. New York: Macmillan Publishing Co. 2002.

Johnson, Paul, D., 1986, Teori Sosiologi Klasik dan Modern, Jakarta: PT. Gramedia.

Kenzie, M.N. A Guide to the Social Sciences.USA:The New American Libtary.1966.

Koran Harian Kompas, 2020

Mead, G. H. 1934. Labeling theory: Social constructionism, Social stigma, Deinstitutionalisation. Chicago: University of Chicago Press 
NCSS. Charting a course: Social studies for the 21st century:commission on social studies in the schools.A report of the curriculum task force of the national Washington: NCSS.1979.

Niponnews, 2020

Poedjiadi, Anna, 2001, Pengantar Filsafat Ilmu Bagi Pendidik, Bandung: Yayasan Cendrawasih.

Sapriya,Pendidikan IPS Konsep dan Pembelajaran. Bandung: PT. RemajaRosdakarya.2012.

Somantri, M. N,.MenggagasPembaharuanPendidikan IPS. Bandung: PT. RemajaRosdakarya.2001.

Sunal, C. Z. and Haas, M. E..Social Studies and The Elementary/Middle School Student, New York: Holt Rinchart and Winston. Inc. 1993

The Japan News, 2020

Undang Undang No. 20 Tahun 2003 tentang Sistem Pendidikan Nasional.

Vibiznews, 2020

Wawan Darmawan,Murdiyah Winarti (2017), Humaniora Di Era Globalisasi, Masihkah Relevan?, Seminar Nasional Sejarah ke 4 Jurusan Pendidikan Sejarah Universitas Negeri Padang.

Wiriaatmadja, Rochiati, 2015, Buku Ajar Filsafat Ilmu Relevansinya dengan Pendidikan IPS, Bandung: Rizqi Press.

Zevin, J..Social Studies for The Twenty-First Century, Methods and Materials for Teaching in Middle and Scondary schools, (Third Edition). New York: Routledge Taylor and Francis Group. 2007. 